1 The cost and benefit of quorum sensing controlled bacteriocin production

\title{
2 in Lactobacillus plantarum
}

3

4 Antonio Maldonado-Barragán* and Stuart A. West

5

6 Department of Zoology, University of Oxford; South Parks Road, OX1 3PS, Oxford, United

$7 \quad$ Kingdom

8

9

10 Corresponding author*:

11

12

13

14

15

16

17

18

19

20

21

22

23

24

25

Antonio Maldonado Barragán

Phone: (+44) 7720126793

Mailing address: 13 High Mill Court, DD2 1UN, Dundee, United Kingdom

e-mail:maldoantonio@gmail.com

Running title: Quorum sensing and Bacteriocins 


\section{Abstract}

Bacteria eliminate competitors via 'chemical warfare' with bacteriocins. Some species appear to adjust bacteriocin production conditionally in response to the social environment. We tested whether variation in the cost and benefit of producing bacteriocins could explain such conditional behaviour, in the bacteria Lactobacillus plantarum. We found that: (1) bacterial bacteriocin production could be upregulated by either the addition of a synthetic autoinducer peptide (PLNC8IF; signalling molecule), or by a plasmid which constitutively encodes for the production of this peptide; (2) bacteriocin production is costly, leading to reduced growth when grown in poor and, to a lesser extent, in rich media; (3) bacteriocin production provides a fitness advantage, when grown in competition with sensitive strains; (4) the fitness benefits provided by bacteriocin production is greater at higher cell densities. These results show how the costs and benefits of upregulating bacteriocin production can depend upon abiotic and biotic conditions.

Keywords: Bacteriocins, Quorum sensing, Costs, Benefits, Fitness

2

3




\section{INTRODUCTION}

The growth and success of many bacteria, both free living and pathogenic, often depends on their ability to eliminate competitors via 'chemical warfare' with bacteriocins (Cotter, Hill, \& Ross, 2005; Riley \& Wertz, 2002). Bacteriocins are small peptides that possess antimicrobial activity against other bacteria, but against which the producing cell has a specific immunity mechanism. Both theoretical and empirical studies have suggested that the production of bacteriocins is a social trait, because the benefits of eliminating competitors are shared with clone mates that also possess immunity (Brown \& Buckling, 2008; Bucci, Nadell, \& Xavier, 2011; Chao \& Levin, 1991; Czárán \& Hoekstra, 2003; Doekes, de Boer, \& Hermsen, 2019; Frank, 1994; Gardner, West, \& Buckling, 2004; Hawlena, Bashey, \& Lively, 2010; Inglis, Gardner, Cornelis, \& Buckling, 2009; Kerr, Riley, Feldman, \& Bohannan, 2002; Libberton, Horsburgh, \& Brockhurst, 2015; Mavridou, Gonzalez, Kim, West, \& Foster, 2018; Waite \& Curtis, 2008; West, Griffin, Gardner, \& Diggle, 2006).

Bacteria appear to adjust bacteriocin production conditionally in response to local conditions, and especially the social environment (Bhattacharya, Pak, \& Bashey, 2018; Gonzalez \& Mavridou, 2019; Majeed, Gillor, Kerr, \& Riley, 2011; Maldonado, Ruiz-Barba, \& Jiménez-Díaz, 2004a). In Escherichia coli, bacteriocin production is increased in response to the presence of bacteriocins produced by competing strains and clone mates (Gonzalez, Sabnis, Foster, \& Mavridou, 2018; Majeed et al., 2011; Mavridou et al., 2018). In Lactobacillus plantarum and Lactobacillus gasseri, bacteriocin production is controlled by a 'quorum sensing' signalling system that causes production to be activated when cells are at higher densities and in the presence of competing bacteria from different species (Maldonado, Jiménez-Díaz, \& Ruiz-Barba, 2004b; Maldonado-Barragán, Ruiz-Barba, \& Jiménez-Díaz, 2009; Maldonado-Barragán, Caballero-Guerrero, Lucena-Padrós, \& Ruiz-Barba, 2013; Maldonado-Barragán, Caballero-Guerrero, Martín, Ruiz-Barba, \& Rodríguez, 2016). 
Evolutionary theory suggests that a potential explanation for these conditional shifts in bacteriocin production is that the relative costs and benefits of bacteriocin production depend upon the social environment (Gardner et al., 2004). For example, producing bacteriocins is predicted to become less beneficial when the density of the competing strains is low (Gardner et al., 2004). However, we know relatively little about how the costs and benefits of bacteriocin production depend upon social conditions (Gonzalez et al., 2018; Gonzalez \& Mavridou, 2019; Inglis et al., 2009).

We examined the cost and benefit of producing bacteriocins, and how this varied with social conditions, in Lactobacillus plantarum NC8 (Figure 1a). This strain regulates bacteriocin production by quorum sensing, leading to bacteriocin production being activated at high cell densities in solid medium, but not in liquid medium (Maldonado et al., 2004b; Maldonado-Barragán et al., 2009). Mechanistically, bacteriocin production in L. plantarum NC8 is activated by co-culturing with other gram-positive bacteria (inducer bacteria), and requires cell-to-cell contact with the inducer bacteria (Maldonado, Ruiz-Barba \& JiménezDíaz, 2003; Maldonado et al., 2004a; Maldonado et al., 2004b). This activates the expression of the operon plNC8IF-plNC8HK-plnD encoding a three-component regulatory system (TCRS) formed by an autoinducer peptide (PLNC8IF), a histidine protein kinase (PLNC8HK) and a response regulator $(\mathrm{P} \operatorname{lnD})$, which is indispensable for bacteriocin production by $\mathrm{NC} 8$ and is thought to be involved in quorum sensing (Maldonado et al., 2004b; MaldonadoBarragán et al., 2009; Figure 1b). Thus, co-culture of NC8 with inducer strains, the external addition of PLNC8IF to NC8 cultures, or the constitutive expression of PLNC8IF in NC8, activates the transcription (via the TCRS) of the genes encoding three two-peptide Class IIb bacteriocins, plantaricin NC8 (PLNC8 $\alpha$ and PLNC8 $\beta$ ), plantaricin EF (plnE and plnF) and plantaricin JK (plnJ and plnK) (Maldonado et al., 2004b).

We can experimentally manipulate bacteriocin production in the L. plantarum NC8 
system in a number of ways. As described above, the wild type NC8 strain only produces bacteriocins under certain conditions. Alternatively, even in absence of inducing bacteria, we can add autoinducer peptide PLNC8IF to activate both PLNC8IF synthesis (autoinduction) and bacteriocin production (Maldonado et al., 2004b; Maldonado et al., 2013). Finally, we can use a recombinant strain NC8:pSIG308, which produces PLNC8IF constitutively - when this PLNC8IF reaches a sufficient concentration it will activate bacteriocin production (Maldonado et al., 2004b).

Our specific aims were to test: (1) whether our experimental and genetic manipulations influence bacteriocin production; (2) whether bacteriocin production is costly; (3) the fitness benefits of bacteriocin production when competing against susceptible strains; (4) whether the fitness benefits of bacteriocin production are greater at higher cell densities.

\section{METHODS}

\section{(a) Bacterial strains and growth media}

We used eight strains in this study, whose main features are summarized in Table 1: (1) Lactobacillus plantarum $\mathrm{NC}$, a wild-type conditional bacteriocin-producer $\left(\mathrm{Bac}^{\mathrm{C}}\right)$ strain that produces QS-regulated bacteriocins on solid medium, but requires co-culture with certain specific inducer strains or the external addition of the autoinducer peptide PLNC8IF to produce bacteriocins in liquid cultures (Maldonado et al., 2004b). Bacteriocins produced belong to the two-peptide ClassIIb bacteriocins, which are released from cells in their active mature form by a dedicated ABC transporter, without cell lysis (Cotter et al., 2005).

(2) L. plantarum NC8:pSIG308 $\left(\mathrm{Bac}^{+}\right)$, is a derivative strain of $\mathrm{NC} 8$ which carries the plasmid pSIG308 (Maldonado et al., 2004a). This plasmid harbours the gene plNC8IF, which encodes the autoinducer peptide PLNC8IF, cloned behind the constitutive lactococcal promoter P53. In contrast to the wild type strain (NC8), NC8:pSIG308 produces PLNC8IF at 
sufficient amounts to activate QS-regulated bacteriocins $\left(\mathrm{Bac}^{+}\right)$and is resistant to erythromycin $(20 \mu \mathrm{g} / \mathrm{ml})$.

(3) L. pentosus 128/2-Rif (NI/S): a Rifampicin resistant (30 $\mu \mathrm{g} / \mathrm{ml})$ derivative strain of $L$. pentosus $128 / 2$. This strain is sensitive (S) to bacteriocins produced by L. plantarum NC8 but does not induces (NI) bacteriocin production in NC8.

(4) Lactococcus lactis MG1363-Rif (I/R): a Rifampicin resistant (30 $\mu \mathrm{g} / \mathrm{ml})$ derivative strain of L. lactis MG1363. This strain is resistant (R) to bacteriocins produced by L. plantarum NC8 and induces (I) bacteriocin production in NC8.

(5) Pediococcus pentosaceus FBB63-Rif (I/S): a Rifampicin resistant (30 $\mu \mathrm{g} / \mathrm{ml})$ derivative of P. pentosaceous FBB63. This strain is sensitive (S) to bacteriocins produced by L. plantarum NC8 and induces (I) bacteriocin production in NC8.

We obtained the strains 128/2-Rif, MG1363-Rif and FBB63-Rif in this study by sequential selection of the wild-type strains 128/2, MG1363 and FBB63 (Table 1), in increasing concentrations of Rifampicin (from 1 to $50 \mu \mathrm{g} / \mathrm{ml}$ ). Unless indicated, we grew all strains at $30^{\circ} \mathrm{C}$ in de Man, Rogosa and Sharpe broth medium (MRS; Oxoid Ltd, Basingstoke, Hampshire, UK) or in MRS agar plates $(1.5 \% \mathrm{w} / \mathrm{v})$. We froze aliquots of each strain at $-80^{\circ} \mathrm{C}$ in MRS plus $20 \%$ glycerol (v/v).

For differential selection of bacteria on solid medium, we used MRS-BPB agar (MRS plus 0.01\% w/v Bromophenol Blue; Sigma-Aldrich), MRS-Rif (MRS plus 30 $\mu \mathrm{g} / \mathrm{ml}$ Rifampicin) and MRS-Ery (MRS plus $100 \mu \mathrm{g} / \mathrm{ml}$ Erythromycin). In MRS-BPB we could easily differentiate NC8 (L. plantarum) from 128/2-Rif (L. pentosus), MG1363-Rif (L. lactis) and FBB63 (P. pentosaceus) since the $\mathrm{pH}$ change produced during fermentation of these Lactic Acid Bacteria changes the colour of accumulated BPB ( $\mathrm{pH}$ indicator), being yellow at $\mathrm{pH} 3.0$ and blue at pH 5.0 (Lee \& Lee, 2008).

For testing the growth of lactobacilli under nutrient limitation, we developed a minimal 
medium (MM) containing K2HPO4 2g L $\mathrm{g}^{-1}$, Sodium acetate monohydrate $5 \mathrm{~g} \mathrm{~L}^{-1}$, MnSO4.H2O $0.0152 \mathrm{~g} \mathrm{~L}^{-1}$ and Tween $800.5 \mathrm{ml} \mathrm{L}^{-1}$. The MM was supplemented with $5 \mathrm{~g} \mathrm{~L}^{-1}$ Yeast Extract $(\mathrm{MM}+\mathrm{YE})$ as nitrogen source.

\section{(b) Bacteriocin Inducing Experiments}

The native PLNC8IF was shown to induce bacteriocin production and its proper synthesis in L. plantarum NC8 through the activation of TCRS (PLNC8IF-PLNC8HK-PLND) (Maldonado et al., 2004b). In this study, we deduced the amino acid sequence of the autoinducer peptide PLNC8IF (KTKTISLMSGLQVPHAFTKLLKALGGHH) from its encoding gene pLNC8IF (accession number: AF522077; Maldonado et al., 2004b), and ordered the chemical synthesis of the peptide (GenScript USA Inc.,NJ). We dissolved one milligram of the peptide ( $>95 \%$ of purity) in $1 \mathrm{ml}$ of Hypure Water (GE Healthcare) and serially diluted to obtain concentrations ranging from 1 to $10^{-12} \mathrm{mg} \mathrm{ml}^{-1}$. To test the ability to induce bacteriocin production in NC8, we added ten microliters of each PLNC8IF dilution to $990 \mu \mathrm{l}$ of MRS containing ca. $10^{8}$ colony forming units per milliliter (CFU/ml) of NC8, thus obtaining final PLNC8IF concentrations ranging from 3 to $310^{-12} \mathrm{mM}$. In control cultures (NC8 without PLNC8IF) we added ten microliters of MRS instead of PLNC8IF. The inducing activity of synthetic PLNC8IF was compared with that of L. lactis MG1363-Rif, whose parental strain, L. lactis MG1363 (I/R), is able to induce bacteriocin production in NC8 trough co-culture (Maldonado et al., 2003; Maldonado et al., 2004a). Specifically, we added ten microliters of a 16-h old culture of MG1363-Rif to NC8 cultures (prepared as described above), giving a final concentration of ca. $10^{7} \mathrm{CFU} / \mathrm{ml}$. In parallel, we compared both the inducing activity of PLNC8IF and MG1363-Rif with the inducing activity of native PLNC8IF, which is endogenously produced by plasmid pSIG308 in the recombinant strain NC8:pSIG308 $\left(\mathrm{Bac}^{+}\right)$. For this, we inoculated NC8:pSIG308 in the same conditions as described above for their parental strain NC8. Cultures were done in triplicate and incubated 
at $30^{\circ} \mathrm{C}$ for seven hours. Bacteriocin activity of cell-free supernatants was quantified as described below. To test for antimicrobial activity of PLNC8IF we carried out serial dilutions of the peptide in MRS medium as described above, and then quantified bacteriocin activity.

\section{(c) Bacteriocin quantification}

For quantification of bacteriocin activity in cell-free supernatants (CFSs) we used a microtiter plate assay, as described previously (Maldonado-Barragán et al., 2013), using L. pentosus 128/2-Rif as the indicator strain. We define one bacteriocin unit (BU) as the amount of active CFS that inhibited the growth of the indicator strain by $50 \%$, using as a reference the turbidity of control cultures without CFS added. This was expressed as the reciprocal of the highest dilution exhibiting 50\% inhibition of the indicator strain per milliliter (BU/ml). Bacteriocin activity per cell (BU/cell) was calculated by dividing bacteriocin activity (BU/ml) by the number of cells $(\mathrm{CFU} / \mathrm{ml})$ at a given point. Before analyses, we log transformed bacteriocin activity $\left(\log _{10} \mathrm{BU} / \mathrm{ml}\right)$ and number of cells $\left(\log _{10} \mathrm{CFU} / \mathrm{ml}\right)$.

\section{(d) Growth curves}

We determined the growth curves of $\mathrm{NC} 8\left(\mathrm{Bac}^{\mathrm{C}}\right)$ (with and without the addition of the autoinducer PLNC8IF) and NC8:pSIG308 $\left(\mathrm{Bac}^{+}\right)$in MRS medium. For this, we diluted 16-h old cultures in MRS until an optical density (measured at 600nm; OD600nm) of 0.01 . We measured the OD600nm in a spectrophotometer (SpectraMax M2; Molecular devices) and recorded with the software SoftMaxPro (Molecular devices). For each strain we prepared six independent cultures, and for each culture we deposited $195 \mu 1$ per well in a 96-wells microtiter plate. In the case of NC8 plus PLNC8IF, we added $5 \mu 1$ of PLNC8IF per well to reach a final concentration of $0.3 \mathrm{mM}$, while in the other cultures (NC8 without PLNC8IF and NC8: pSIG308) we added $5 \mu 1$ of MRS. We used non-inoculated MRS as the blank control. We then incubated plates at $30^{\circ} \mathrm{C}$ for 48 hours, in a Synergy 2 Multi-Mode Reader (BioTek), measuring OD600nm at 15 min intervals. We recorded OD600nm data and maximum growth 
rate (Vmax), and analyzed with the "Gen5 Data Analysis Software" (BioTek).

We carried out the same experiment under nutrient limitation, using $\mathrm{MM}+\mathrm{YE}$ as culture media. For this, we washed (two times) 16-h old cultures of each strain (NC8 and NC8:pSIG308) and diluted cultures in MM+YE until an OD600nm of 0.01. We prepared and incubated the 96-wells plate in the same conditions we described above, using MM+YE as the blank. For each strain (NC8, NC8+PLNC8IF and NC8:pSIG308), we obtained six growth curves in each culture media (MM+YE and MRS).

\section{(e) Competition assays}

\section{(e.1) General protocol}

We did competition assays to measure the fitness cost/benefits of producing bacteriocins,

211 rather than estimating the metabolic costs/benefits directly. Before each competition

212 experiment, we thawed frozen stocks $\left(-80^{\circ} \mathrm{C}\right)$ of each strain used, inoculated in MRS broth

213 and incubated at $30^{\circ} \mathrm{C}$ for 16 hours without agitation. Later, we diluted each culture separately

214 in MRS to reach an OD600nm of 0.01 (ca. $1 \times 10^{7} \mathrm{CFU} / \mathrm{ml}$ ) in order to ensure similar

215 numbers of bacteria per milliliter. Finally we mixed the competing strains (at a proportion of

$21650 \%$ ) to reach a final titre of ca. $1 \times 10^{5} \mathrm{CFU} / \mathrm{ml}$ and incubated a $30^{\circ} \mathrm{C}$ for $24 \mathrm{~h}$ without

217 agitation. We determined the $\mathrm{CFU} / \mathrm{ml}$ for each strain in the mix before (initial point at 0 -h)

218 and after $24-\mathrm{h}$ incubation at $30^{\circ} \mathrm{C}$ (final point). To calculate $\mathrm{CFU} / \mathrm{ml}$, we diluted the cultures

219 in saline $(\mathrm{NaCl} 0.85 \% \mathrm{w} / \mathrm{v})$ and spread appropriate dilutions on MRS-BPB, MRS-Rif or 220 MRS-Ery agar plates. Bacteriocin activity in mixed cultures was quantified as described 221 above.

222 (e.2) Costs/Benefits of bacteriocin production triggered by PLNC8IF

223 We measured the relative fitness $(w)$ of $\mathrm{NC} 8\left(\mathrm{Bac}^{\mathrm{C}}\right)$ in competition with 128/2-Rif (NI/S), 224 with and without the addition of the autoinducer peptide PLNC8IF. We distributed aliquots of $990 \mu 1$ from mixed cultures into $1-\mathrm{ml}$ tubes and then we added $10 \mu 1$ of PLNC8IF to reach 
final concentrations of $0.003,0.03,0.3$ and 3 millimolar $(\mathrm{mM})$. In control experiments (mixed cultures without PLNC8IF) we added $10 \mu 1$ of MRS. Each treatment was repeated between 8 and 11 times, thus obtaining a total of 46 independent replicates, distributed as follows: control experiments $(n=11)$; treatment with PLNC8IF: $0.003 \mathrm{mM}(\mathrm{n}=8), 0.03 \mathrm{mM}(\mathrm{n}=11), 0.3$ $\mathrm{mM}(\mathrm{n}=8), 3 \mathrm{mM}(\mathrm{n}=8)$.

We also measured the relative fitness $(w)$ of NC8:pSIG308 $\left(\mathrm{Bac}^{+}\right.$; produces PLNC8IF and therefore bacteriocins) against 128/2-Rif (NI/S), without the external addition of synthetic PLNC8IF. We carried out competition experiments as described above, independently replicating each treatment 16 times $(n=16)$. This competition experiment allowed us to test the fitness consequences of constitutively producing PLNC8IF, compared with our previous experiment, which examined the consequences of adding synthetic PLNC8IF

\section{(e.3) Costs/Benefits of bacteriocin production triggered by inducer strains}

We measured the relative fitness $(w)$ of $\mathrm{NC} 8\left(\mathrm{Bac}^{\mathrm{C}}\right)$ in competition with either FBB63-Rif (I/S) or MG1363-Rif (I/R). Both these two strains induce bacteriocin production in NC8, but one is sensitive (FBB63-Rif), and the other is resistant (MG1363-Rif) to such bacteriocins. We replicated each competition 7 times $(n=7)$.

\section{(e.4) Density and fitness}

We tested if the relative fitness benefit of producing bacteriocins depends upon cell density, by conducting competition experiments between $\mathrm{NC} 8\left(\mathrm{Bac}^{\mathrm{C}}\right)$ and 128/2-Rif (NI/S) across a range of cell densities $\left(10^{2}, 10^{4}, 10^{6}\right.$ and $\left.10^{8} \mathrm{CFU} / \mathrm{ml}\right)$. We induced bacteriocin production artificially, with the addition of PLNC8IF ( $0.3 \mathrm{mM}$ final concentration), so that bacteriocins would produce even at low densities (Darch, West, Winzer, \& Diggle, 2012). We mixed the competing strains at equal starting frequencies (50\% each) and serially diluted to obtain mixed cultures at different starting cell densities $\left(10^{2}, 10^{4}, 10^{6}\right.$ and $\left.10^{2} \mathrm{CFU} / \mathrm{ml}\right)$. After incubation at $30^{\circ} \mathrm{C}$ for $4 \mathrm{~h}$, we calculated the growth of NC8 to that of the competitor strain by 
determining the $\mathrm{CFU} / \mathrm{ml}$ for each strain at $0 \mathrm{~h}$ (initial) and after 4-h incubation (final). CFS

252

253

254

255

256

257

258 were quantified for bacteriocin activity as described above. We repeated each treatment five times, obtaining four-five independent replicates of each cell density as follows: $10^{2}(n=4)$, $10^{4}(\mathrm{n}=5), 10^{6}(\mathrm{n}=5)$ and $10^{8}(\mathrm{n}=5)$.

\section{(i) Statistical analyses}

We measured the relative fitness of a given strain $(w)$ by the equation $w=p_{2}\left(1-p_{1}\right) / p_{1}\left(1-p_{2}\right)$, where $p_{1}$ is the initial proportion of the strain, and $p_{2}$ is the proportion after growth (RossGillespie, Gardner, West, \& Griffin, 2007). The value of $w$ signifies whether the strain increases $(w>1)$, decreases $(w<1)$ or stays at the same $(w=1)$ frequency. We obtained the same conclusions when repeating our analyses, logging the raw values of $\mathrm{w}$ before calculating the mean for each independent replicate, to test for any biases arising from within replicate variation in $w$ (Jiricny et al., 2010). We used standard general linear models (GLMs) implemented in IBM SPSS statistics (v. 22). The curves shown are regression lines fitted to the raw data.

\section{RESULTS}

\section{(a) Inducing Bacteriocin production}

Bacteriocin production was increased by both the constitutive expression of PLNC8IF by the plasmid pSIG308 (NC8:pSIG308, constitutive producer) and the addition of cells of an inducing strain, L. lactis MG1363-Rif (I/R) (Figure 2a; $\mathrm{F}_{1,7}=394.3, \mathrm{p}<0.01$ ). We were also able to induce bacteriocin production by addition of synthetic peptide PLNC8IF, with larger amounts of peptide leading to greater bacteriocin production (ANOVA: $F_{1,13}=222.3$, $\mathrm{p}<0.001, \mathrm{r}^{2}=0.942$; Figure 2b).

\section{(b) Cost of producing bacteriocins}


We upregulated bacteriocin production in two ways, by the addition of synthetic PLNC8IF, and by the constitutively expressed plasmid pSIG308. In a minimal medium supplemented with yeast extract $(\mathrm{MM}+\mathrm{YE})$, we found that upregulating bacteriocin production led to reduced growth in the exponential phase of growth (Figure 3a), with a decreased maximum growth rate $(\operatorname{Vmax})$ (ANOVA: $\mathrm{F}_{1,16}=13.77, \mathrm{p}=0.002, \mathrm{R}^{2}=0.463$; Figure $3 \mathrm{~b}$ ), and a lower final cell density $\left(\mathrm{F}_{1}, 16=8.18, \mathrm{p}=0.012\right.$; no significant difference in growth between the PLNC8IF and pSIG308 manipulations: $\mathrm{F}_{1,10}=1.70, \mathrm{p}=0.22$ ) (Figure 3a\&c) .

In a nutrient rich media, de Man, Rogosa and Sharpe (MRS), we found that upregulating bacteriocin production led to a reduced growth in the exponential phase of growth (Figure 3d), with a decreased Vmax with the addition of PLNC8IF (NC8+PLNC8IF; ANOVA: $\left.\mathrm{F}_{1,10}=17.45, \mathrm{p}=0.002\right)$ but not constitutive expression of PLNC8IF (NC8:pSIG308; ANOVA: $\mathrm{F}_{1,10}=0.30, \mathrm{p}=0.59$ ) (Figure 3e). There was no influence on final cell density (ANOVA: $\mathrm{F}_{1,16}=0.27, \mathrm{p}=0.61$; no significant difference in growth between the PLNC8IF and pSIG308 manipulations: $\mathrm{F}_{1,10}=1.05, \mathrm{p}=0.33$ ) (Figure $3 \mathrm{~d} \& \mathrm{f}$ ).

\section{(c) Fitness Benefit of Producing Bacteriocins}

We tested whether bacteriocin production conferred a benefit to the producing strain, when competing with L. pentosus 128/2-Rif (NI/S) a strain which is sensitive to bacteriocins produced by NC8. We upregulated bacteriocin production in two ways: (i) both the constitutive expression of PLNC8IF by the plasmid pSIG308 (constitutive producer); and (ii) addition of synthetic PLNC8IF.

In both cases, we found that increased bacteriocin provided a fitness benefit when in competition with L. pentosus 128/2-Rif (NI/S). The constitutive producer (NC8:pSIG308; $\mathrm{Bac}^{+}$) produced more bacteriocin per cell (Figure 4a; ANOVA: $\mathrm{F}_{1,26}=119.95, \mathrm{p}<0.001$ ), and had a higher relative fitness than the wild type NC8 $\left(\mathrm{Bac}^{\mathrm{C}}\right)$ strain (Figure 4b; ANOVA: F1,32= 
52.36, $\mathrm{p}<0.001$ ), which only produces bacteriocins conditionally. The addition of synthetic

302 PLNC8IF also led to increased bacteriocin production per cell (Figure 4c; ANOVA: F1,44= 688.95, $\left.\mathrm{p}<0.001 ; \mathrm{R}^{2}=0.940\right)$, and that increased bacteriocin production led to an increase in fitness until a maximum after which the fitness benefits level off (Figure 4b; ANOVA: F2,43 $\left.=174.70, \mathrm{p}<0.001 ; \mathrm{R}^{2}=0.890\right)$.

(d) Fitness benefit and cost of activating bacteriocin production after cell-to-cell contact with inducer strains

We also tested the relative benefit of QS controlled bacteriocin production by competing our conditional bacteriocin producing strain (NC8) against two strains which both induce bacteriocin production, but where one strain is sensitive to the bacteriocins produced by NC8 (FBB63-Rif; I/S), and the other strain is resistant (MG1363-Rif; I/R). Consistent with a net benefit of bacteriocin production originating from the killing competitors, we found that our conditional bacteriocin producing strain (NC8) had a higher fitness than the sensitive strain (FBB63-Rif; $\mathrm{t}_{6}=58.10, \mathrm{p}<0.001$ ) (Figure 5). In contrast, the fitness of the conditional bacteriocin producing strain (NC8) was slightly lower than the resistant strain (MG1363-Rif; $t_{6}=-2.69, p=0.036$ ) (Figure 5). Although the fitness difference versus the resistant strain is small, and there are other genetic differences between the lines, this result is consistent with a cost of bacteriocin production, in a situation where there is no benefit.

\section{(e) Density assays}

322 We then tested whether the benefits of bacteriocin production were greater at higher cell densities. We added synthetic PLNC8IF to activate bacteriocin production in the conditional producing strain $\left(\mathrm{NC} 8 ; \mathrm{Bac}^{\mathrm{C}}\right)$, when grown in competition with a sensitive non-inducing strain (128/2-Rif; NI/S), at a range of different starting densities. At higher starting densities, 
the relative fitness of the bacteriocin producing PLNC8IF strain was greater (ANOVA: $F_{1,17}=$ 79.51, $\mathrm{p}<0.001, \mathrm{R}^{2}=0.824$; Figure $6 \mathrm{~b}$ ). Although we found that bacteriocin production was induced by the addition of synthetic PLNC8IF, this result could be confounded by cell density, which also positively correlates with bacteriocin production (ANOVA: $F_{1,18}=$ 164.92, $\mathrm{p}<0.001, \mathrm{R}^{2}=0.902$; Figure 6a). Although in a multiple regression, the relative fitness of the bacteriocin producing strain was greater both when they produced more bacteriocins $\left(\mathrm{F}_{1,16}=17.64, \mathrm{p}=0.001\right)$, and at higher cell densities $\left(\mathrm{F}_{1,16}=5.59, \mathrm{p}=0.031\right)$.

\section{DISCUSSION}

We examined the social cost and benefit of quorum sensing (QS) controlled bacteriocin production in the bacteria L. plantarum NC8. We found that: (1) bacteriocin production could be induced by the addition of a synthetic PLNC8IF peptide, or by a plasmid which constitutively encodes for the production of this peptide (Figure 2); (2) bacteriocin production is costly, leading to reduced growth when grown in poor and, to a lesser extent, in rich media (Figure 3), and when in competition with resistant bacteria (Figure 6); (3) bacteriocin production provides a fitness advantage, when grown in competition with sensitive strains (Figures 4-6); (4) the fitness benefits provided by bacteriocin production is greater at higher cell densities (Figure 6).

\section{Quorum sensing and the benefits of bacteriocin production}

It is frequently assumed that bacteria use quorum sensing to conditionally switch on certain behaviours when they are relatively more beneficial. In particular, it is thought that quorum sensing is used to turn on cooperative behaviours at high densities, when they would provide a greater benefit (Brown \& Johnstone, 2001; West, Winzer, Gardner, \& Diggle, 2012). However, there are few studies that have tested this assumption (Darch et al., 2012; 
Koschwanez, Foster, \& Murray, 2013). We have shown here, consistent with quorum sensing theory, that quorum sensing controlled bacteriocin production provides a greater benefit at higher cell densities (Figure 7).

The benefits of producing QS-regulated bacteriocins could be greater at high densities because: (a) greater cell-to-cell contact with inducer bacteria can increase bacteriocin effectivity; (b) bacteriocins could reach sensitive strains at a greater rate; (c) the benefits of killing competitors, via reduced resource competition, could be greater; (d) the benefits of producing bacteriocins and killing the sensitive strain, freeing-up resources, could be more likely to be shared with clone mates. A potential problem with our density manipulation is that it also altered bacteriocin production (Figure 6a). Although our results suggest that both bacteriocin production and density have an influence, it would be useful to develop a density manipulation that did not have any other potentially confounded influences. In addition, it is also important to note that initial frequency of bacteriocin producer relative to the sensitive strain can influence the relative benefit of producing bacteriocins (Gardner et al. 2004; Inglis et al., 2009). Our experiments were carried out at intermediate frequencies (each strain at $50 \%$ ), where bacteriocins are expected to confer the greatest fitness advantage from killing competitors, by reducing competition for both the bacteriocin producing cells and their relatives (Gardner et al., 2004; Inglis et al., 2009).

\section{The cost of producing bacteriocins}

We found that producing bacteriocins reduced growth rate, in both poor and rich media, and reduced final cell density in poor, but not rich media (Figure 3). This is consistent with previous results finding that the cost of traits are reduced or eliminated when the resources for producing them are not limited (Sexton \& Schuster, 2017; Xavier, Kim, \& Foster, 2011). When growing alone either in poor or in rich medium, NC8 produce little or no bacteriocins, 
thus avoiding the cost of producing bacteriocins when not required (no benefit of killing competitors). In addition, we found that in rich medium the relative fitness of NC8 depend on their social environment, which is determined by the resistance/sensitivity of the social partner (competing strain) to bacteriocins produced by NC8.

\section{Conditional bacteriocin production}

In NC8, conditional bacteriocin production could be seen as a mechanism directed to save metabolic costs when there is less benefit to their production. In absence of competitors, the QS mechanism is not active which avoids costly bacteriocin production when there is little benefit. In contrast, when a competing strain is sufficiently common, such that it would be beneficial to eliminate them with bacteriocins, and there are sufficient NC8 to produce those bacteriocins, their production is upregulated (Figure 1a). In nature, there could be selection to detect "sensitive" competitors or to avoid being detected - although there is no evidence yet for this, it could help explain the existence of non-inducer strains that are resistant to bacteriocins. Mechanistically, the co-culture with certain specific strains (inducer bacteria) belonging to different species led to the activation of the QS system in NC8, activating production of the autoinducer PLNC8IF and therefore production of bacteriocins (Figure 1b) (Maldonado et al., 2004a; Maldonado et al., 2004b). Thus, in NC8, bacteriocin production depends on first instance on the identity of the interacting partner (Maldonado et al., 2004b), and second, on the ability to reach a QS driven by the autoinducer peptide PLNC8IF (Figure 1a) (Maldonado et al., 2004a; Maldonado-Barragán et al., 2009). This implies that quorum sensing information is used not only for signalling among self-cells, but also integrated with the detection of specific cues produced by other genotypes (for detecting evolutionary competition; Cornforth \& Foster (2013). 
We have demonstrated that bacteriocin production can be costly, but that it can provide a benefit when competing against susceptible strains. Furthermore, that the benefits are greater at higher cell densities. These results provide an explanation for why bacteriocin production should be controlled by quorum sensing, and preferentially turned on at higher cell densities. More generally, we build upon previous results, which emphasise the advantage of conditionally adjusting bacteriocin production, in response to the social environment (Gardner et al., 2004; Gonzalez et al., 2018; Gonzalez \& Mavridou, 2019; Majeed et al., 2011; Mavridou et al., 2018).

\section{Acknowledgments}

412 We thank Dr. John

B. Bruce and Dr. Melanie Ghoul for discussion and support in the laboratory, and comments on the manuscript. We thank two anonymous reviewers and Dr.

Christoph Haag for comments on the manuscript. We thank to the Spanish National Research

Council (CSIC) and Instituto de la Grasa-CSIC for the administrative management of the Andalucia Talent Hub program and providing access to the bacterial strains used in this work.

This study was funded by the Andalucía Talent Hub Program launched by the Andalusian Knowledge Agency, co-funded by the European Union's Seventh Framework Program, Marie Skłodowska-Curie actions (COFUND - Grant Agreement $n^{\circ}$ 291780) and the Ministry of Economy, Innovation, Science and Employment of the Junta de Andalucía.

\section{REFERENCES}

1. Bhattacharya, A., Pak, H. T.-Y., \& Bashey, F. (2018). Plastic responses to competition: 
2. Brown, S. P., \& Johnstone, R. A. (2001). Cooperation in the dark: signalling and collective action in quorum-sensing bacteria. Proceedings of the Royal Society of London. Series B: Biological Sciences, 268, 961-965. https://doi.org/10.1098/rspb.2001.1609

3. Brown, S. P., \& Buckling, A. (2008). A social life for discerning microbes. Cell, 135, 600603. https://doi.org/10.1016/j.cell.2008.10.030

4. Bucci, V., Nadell, C. D., \& Xavier, J. B. (2011). The Evolution of Bacteriocin Production in Bacterial Biofilms. The American Naturalist, 178, E162-E173. https://doi.org/10.1086/662668

5. Chao, L., \& Levin, B. R. (1981). Structured habitats and the evolution of anticompetitor toxins in bacteria. Proceedings of the National Academy of Sciences, 78, 6324-6328. https://doi.org/10.1073/pnas.78.10.6324

6. Cornforth, D. M., \& Foster, K. R. (2013). Competition sensing: the social side of bacterial stress responses. Nature Reviews Microbiology, 11, 285-293. https://doi.org/10.1038/nrmicro2977

7. Cotter, P. D., Hill, C., \& Ross, R. P. (2005). Bacteriocins: developing innate immunity for food. Nature Reviews Microbiology, 3, 777-788. https://doi.org/10.1038/nrmicro1273

8. Czárán, T. L., \& Hoekstra, R. F. (2003). Killer-sensitive coexistence in metapopulations of micro-organisms. Proceedings of the Royal Society of London. Series B: Biological Sciences, 270, 1373-1378. https://doi.org/10.1098/rspb.2003.2338

9. Darch, S. E., West, S. A., Winzer, K., \& Diggle, S. P. (2012). Density-dependent fitness benefits in quorum-sensing bacterial populations. Proceedings of the National Academy of Sciences, 109, 8259-8263. https://doi.org/10.1073/pnas.1118131109

10. Doekes, H. M., de Boer, R. J., \& Hermsen, R. (2019). Toxin production spontaneously becomes regulated by local cell density in evolving bacterial populations. PLOS Computational Biology, 15, e1007333. https://doi.org/10.1371/journal.pcbi.1007333 
11. Frank, S. A. (1994). Spatial polymorphism of bacteriocins and other allelopathic traits. Evolutionary Ecology, 8, 369-386. https://doi.org/10.1007/bf01238189

12. Gardner, A., West, S. A., \& Buckling, A. (2004). Bacteriocins, spite and virulence. Proceedings of the Royal Society of London. Series B: Biological Sciences, 271, 15291535. https://doi.org/10.1098/rspb.2004.2756

13. Gonzalez, D., Sabnis, A., Foster, K. R., \& Mavridou, D. A. I. (2018). Costs and benefits of provocation in bacterial warfare. Proceedings of the National Academy of Sciences, 115, 7593-7598. https://doi.org/10.1073/pnas.1801028115

14. Gonzalez, D., \& Mavridou, D. A. I. (2019). Making the Best of Aggression: The Many Dimensions of Bacterial Toxin Regulation. Trends in Microbiology. https://doi.org/10.1016/j.tim.2019.05.009

15. Hawlena, H., Bashey, F., \& Lively, C. M. (2010). The evolution of spite: population structure and bacteriocin-mediated antagonism in two natural populations of Xenorhabdus bacteria. Evolution, 64, 3198-3204. https://doi.org/10.1111/j.1558-5646.2010.01070.x

16. Inglis, R. F., Gardner, A., Cornelis, P., \& Buckling, A. (2009). Spite and virulence in the bacterium Pseudomonas aeruginosa. Proceedings of the National Academy of Sciences, 106, 5703-5707. https://doi.org/10.1073/pnas.0810850106

17. Jiricny, N., Diggle, S. P., West, S. A., Evans, B. A., Ballantyne, G., Ross-Gillespie, A., \& Griffin, A. S. (2010). Fitness correlates with the extent of cheating in a bacterium. Journal of Evolutionary Biology, 23, 738-747. https://doi.org/10.1111/j.1420-9101.2010.01939.x

18. Kerr, B., Riley, M. A., Feldman, M. W., \& Bohannan, B. J. M. (2002). Local dispersal promotes biodiversity in a real-life game of rock-paper-scissors. Nature, 418, 171-174. https://doi.org/10.1038/nature00823

19. Koschwanez, J. H., Foster, K. R., \& Murray, A. W. (2013). Improved use of a public good selects for the evolution of undifferentiated multicellularity. eLife, 2. 
https://doi.org/10.7554/elife.00367

20. Lee, H. M., \& Lee, Y. (2008). A differential medium for lactic acid-producing bacteria in a mixed culture. Letters in Applied Microbiology, 46, 676-681. https://doi.org/10.1111/j.1472-765x.2008.02371.x

21. Libberton, B., Horsburgh, M. J., \& Brockhurst, M. A. (2015). The effects of spatial structure, frequency dependence and resistance evolution on the dynamics of toxinmediated microbial invasions. Evolutionary Applications, 8, 738-750. https://doi.org/10.1111/eva.12284

22. Majeed, H., Gillor, O., Kerr, B., \& Riley, M. A. (2011). Competitive interactions in Escherichia coli populations: the role of bacteriocins. The ISME Journal, 5, 71-81. https://doi.org/10.1038/ismej.2010.90

23. Maldonado, A., Ruiz-Barba, J. L., \& Jiménez-Díaz, R. (2003). Purification and genetic characterization of plantaricin NC8, a novel coculture-inducible two-peptide bacteriocin from Lactobacillus plantarum NC8. Applied and Environmental Microbiology, 69, 383389. https://doi.org/10.1128/aem.69.1.383-389.2003

24. Maldonado, A., Ruiz-Barba, J. L., \& Jiménez-Díaz, R. (2004). Production of plantaricin NC8 by Lactobacillus plantarum NC8 is induced in the presence of different types of grampositive bacteria. Archives of Microbiology, 181, 8-16. https://doi.org/10.1007/s00203-0030606-8

25. Maldonado, A., Jiménez-Díaz, R., \& Ruiz-Barba, J. L. (2004). Induction of plantaricin production in Lactobacillus plantarum NC8 after coculture with specific Gram-positive bacteria is mediated by an autoinduction mechanism. Journal of Bacteriology, 186, 15561564. https://doi.org/10.1128/jb.186.5.1556-1564.2004

26. Maldonado-Barragán, A., Ruiz-Barba, J. L., \& Jiménez-Díaz, R. (2009). Knockout of threecomponent regulatory systems reveals that the apparently constitutive plantaricin- 
production phenotype shown by Lactobacillus plantarum on solid medium is regulated via quorum sensing. International Journal of Food Microbiology, 130, 35-42. https://doi.org/10.1016/j.ijfoodmicro.2008.12.033

27. Maldonado-Barragán, A., Caballero-Guerrero, B., Lucena-Padrós, H., \& Ruiz-Barba, J. L. (2013). Induction of bacteriocin production by coculture is widespread among plantaricinproducing Lactobacillus plantarum strains with different regulatory operons. Food Microbiology, 33, 40-47. https://doi.org/10.1016/j.fm.2012.08.009

28. Maldonado-Barragán, A., Caballero-Guerrero, B., Martín, V., Ruiz-Barba, J. L., \& Rodríguez, J. M. (2016). Purification and genetic characterization of gassericin E, a novel co-culture inducible bacteriocin from Lactobacillus gasseri EV1461 isolated from the vagina of a healthy woman. BMC Microbiology, 16(1). https://doi.org/10.1186/s12866-0160663-1

29. Mavridou, D. A. I., Gonzalez, D., Kim, W., West, S. A., \& Foster, K. R. (2018). Bacteria use collective behavior to generate diverse combat strategies. Current Biology, 28, 345355.e4. https://doi.org/10.1016/j.cub.2017.12.030

30. Riley, M. A., \& Wertz, J. E. (2002). Bacteriocins: evolution, ecology, and application. Annual Review of Microbiology, 56, 117-137. https://doi.org/10.1146/annurev.micro.56.012302.161024

31. Ross-Gillespie, A., Gardner, A., West, S. A., \& Griffin, A. S. (2007). Frequency dependence and cooperation: theory and a test with bacteria. The American Naturalist, 170, 331-342. https://doi.org/10.1086/519860

32. Sexton, D. J., \& Schuster, M. (2017). Nutrient limitation determines the fitness of cheaters in bacterial siderophore cooperation. Nature Communications, 8(1). https://doi.org/10.1038/s41467-017-00222-2

33. Shrago, A.W., Chassy, B.M., \& Dobrogosz, W.J., 1986. Conjugal plasmid transfer 

576.

34. Waite, R. D., \& Curtis, M. A. (2008). Pseudomonas aeruginosa PAO1 pyocin production affects population dynamics within mixed-culture biofilms. Journal of Bacteriology, 191, 1349-1354. https://doi.org/10.1128/jb.01458-08

35. West, S. A., Griffin, A. S., Gardner, A., \& Diggle, S. P. (2006). Social evolution theory for microorganisms. Nature Reviews Microbiology, 4, 597-607. https://doi.org/10.1038/nrmicro1461

36. West, S. A., Winzer, K., Gardner, A., \& Diggle, S. P. (2012). Quorum sensing and the confusion about diffusion. Trends in Microbiology, 20, 586-594. https://doi.org/10.1016/j.tim.2012.09.004

37. Xavier, J. B., Kim, W., \& Foster, K. R. (2011). A molecular mechanism that stabilizes cooperative secretions in Pseudomonas aeruginosa. Molecular Microbiology, 79, 166-179. https://doi.org/10.1111/j.1365-2958.2010.07436.x

\section{FIGURE LEGENDS}

Figure 1. (a) Conditional Bacteriocin Production in L. plantarum NC8 depends upon the social environment. Bacteriocin upregulation requires both a signal of sufficient clonemate density (assessed via QS) and sufficient density of unrelated competitors (assessed via cell-tocell contact). (b) Model of Regulation of Bacteriocin Production in Lactobacillus plantarum NC8. The cell-to-cell contact with inducer bacteria activates the expression (through a hitherto unknown mechanism) of the operon plNC8IFHK-plnD encoding a threecomponent regulatory system, formed by an autoinducer peptide (PLNC8IF) a histidine protein kinase $(\mathrm{PLNC} 8 \mathrm{HK})$ and a response regulator $(\mathrm{PlnD})$. As consequence of this 
551 interaction, the autoinducer peptide PLNC8IF is produced. Once PLNC8IF reaches the 552 threshold concentration (Quorum sensing) is sensed by their corresponding histidine kinase PLNC8HK, which activates the response regulator PlnD through phosphorylation. Active$\mathrm{PlnD}$ induces the expression of the genes involved in bacteriocin production in NC8 as well as the proper TCRS (autoinduction).

Figure 2. Validating strains. (a) Bacteriocin activity of the conditional bacteriocin producer L. plantarum $\mathrm{NC} 8\left(\mathrm{Bac}^{\mathrm{C}}\right)$ when grown as single culture $(\mathrm{NC} 8)$ or in co-culture with the inducer bacteria L. lactis MG1363-Rif (I/R) (NC8+MG1363), and its derivative strain NC8:pSIG308 $\left(\mathrm{Bac}^{+}\right)$that constitutively produces the autoinducer peptide (PLNC8IF). Both the co-culture with L. lactis and the production of PLNC8IF driven by plasmid pSIG308 led to increased bacteriocin production. (b) The addition of larger amounts of synthetic PLNC8IF peptide leads to greater bacteriocin production in L. plantarum NC8. Error bars were not displayed because they are too small to be seen.

Figure 3. Bacteriocin production is costly. Growth curves, maximum growth rates (Vmax) and final cell densities in nutrient poor $(\mathrm{MM}+\mathrm{YE})$ media $(\mathrm{a}, \mathrm{b}$ and $\mathrm{c})$ and nutrient rich (MRS) media (d, e and f). Data are shown for the conditional bacteriocin producer strain producing negligible bacteriocins (L. plantarum $\mathrm{NC} 8 ; \mathrm{Bac}^{\mathrm{C}}$ ), and two strains producing appreciable bacteriocins: NC8 with added PLNC8IF autoinducer (NC8+PLNC8IF; $\mathrm{Bac}^{+}$) and the constitutive PLNC8IF producer (NC8:pSIG308; $\mathrm{Bac}^{+}$). OD600nm measurements are means for

572 six replicates. The addition of PLNC8IF peptide and constitutive PLNC8IF production both 573 led to reduced growth in nutrient poor media, but not in nutrient rich media, although there 
culture media. Error bars, which represent standard errors, were not displayed in figure $3 \mathrm{~d}$

576 because they are too small to be seen.

577

578

579

580

581

582

583

584

Figure 4. Benefit of Bacteriocin Production. Bacteriocin activity (a) and relative fitness (b) of the conditional bacteriocin producer $\left(\mathrm{NC} 8 ; \mathrm{Bac}^{\mathrm{C}}\right)$ and the constitutive PLNC8IF producer (NC8:pSIG308; $\mathrm{Bac}^{+}$) when in competition with L. pentosus 128/2-Rif (sensitive strain; NI/S). The constitutive producer both produced more bacteriocins, and had a higher relative fitness, when compared with the conditional producer. Bacteriocin activity (c) and relative fitness (d) of the conditional bacteriocin producer L. plantarum $\mathrm{NC} 8\left(\mathrm{Bac}^{\mathrm{C}}\right)$, when in competition with L. pentosus 128/2-Rif (sensitive strain; NI/S) after the initial addition of increasing concentrations of the autoinducer peptide PLNC8IF. The addition of PLNC8IF induced bacteriocin production in NC8, increasing its fitness against the sensitive strain 128/2-Rif, although this increase in fitness approached an asymptote or even peaked. Relative fitness $(w)$ was estimated relative to the sensitive strain, and plotted on a log scale. Bacteriocin activity was expressed as bacteriocin units per cell (BU/cell). mM, millimolar. The curves are regression lines fitted to the raw data.

Figure 5. The Cost and Benefit of naturally induced bacteriocin production. The relative fitness of the conditional bacteriocin producing strain $\mathrm{NC} 8\left(\mathrm{Bac}^{\mathrm{C}}\right)$ is shown when grown with inducing strains that are: (a) sensitive (FBB63-Rif; I/S); and (b) resistant (MG1363-Rif; I/R) to the bacteriocins produced by NC8. Relative fitness $(w)$ was plotted on log scale.

Figure 6. Density-dependent fitness benefits of responding to QS. Bacteriocin activity (a) and relative fitness (b) of the conditional bacteriocin producer L. plantarum $\mathrm{NC} 8\left(\mathrm{Bac}^{\mathrm{C}}\right)$, when in competition with the sensitive L. pentosus 128/2-Rif strain (NI/S) at different starting 
600 cell densities (from $10^{2}$ to $10^{8}$ cells per millilitre). The fitness benefit of adding signal 601 (PLNC8IF), and therefore inducing QS and bacteriocin production in the conditional producer 602 L. plantarum NC8 was greater at higher population densities. The dashed lines indicate if the 603 conditional producer NC8 increases $(\mathrm{w}>1)$, decreases $(\mathrm{w}<1)$ or remains at the same frequency $604(\mathrm{w}=1)$.

605

606

607

608

609

610 
611 Table 1. Bacterial strains used in this study

\begin{tabular}{|c|c|c|c|c|c|}
\hline Strains & Characteristics & $\begin{array}{l}\text { Bacteriocin } \\
\text { Production }\end{array}$ & $\begin{array}{l}\dagger \text { Resistant (R) } \\
\text { /Sensitive (S) }\end{array}$ & $\begin{array}{c}\text { \$Inducer (I) } \\
\text { /Non-inducer (NI) }\end{array}$ & Reference \\
\hline Lactobacillus plantarum $\mathrm{NC} 8 *$ & $\begin{array}{l}\text { Inducible plantaricins (PLNC8 } \alpha \beta \text {, PlnEF and PlnJK) } \\
\text { producer }\end{array}$ & Conditional $\left(\mathrm{Bac}^{\mathrm{C}}\right)$ & $\mathrm{R}$ & NI & $\begin{array}{l}\text { Shrago, Chassy and Dobrogosz } \\
\text { (1986) } \\
\text { Maldonado et al. (2003; 2004b) }\end{array}$ \\
\hline L. plantarum NC8:pSIG308 & $\begin{array}{l}\text { Derivative of NC8; Produces PLNC8IF constitutively from } \\
\text { plasmid pSIG308. Erm }{ }^{\mathrm{R}}\end{array}$ & Constitutive $\left(\mathrm{Bac}^{+}\right)$ & $\mathrm{R}$ & I & Maldonado et al. (2004b) \\
\hline Lactobacillus pentosus $128 / 2$ & Indicator strain for bacteriocin activity & Negative $\left(\mathrm{Bac}^{-}\right)$ & $\mathrm{S}$ & NI & Maldonado et al. (2003) \\
\hline L. pentosus 128/2-Rif & Derivative of $L$. pentosus $128 / 2 ; \mathrm{Rif}^{\mathrm{R}}$ & Negative (Bac') & $\mathrm{S}$ & NI & This work \\
\hline Lactococcus lactis MG1363 & Indicator strain for bacteriocin activity & Negative (Bac') & $\mathrm{R}$ & I & Maldonado et al. (2003) \\
\hline L. lactis MG1363-Rif & Derivative of L. lactis MG1363; Rif ${ }^{\mathrm{R}}$ & Negative (Bac') & $\mathrm{R}$ & I & This work \\
\hline Pediococcus pentosaceus FBB63 & Indicator strain for bacteriocin activity & Negative (Bac') & $\mathrm{S}$ & I & Maldonado et al. (2003) \\
\hline P. pentosaceus FBB63-Rif & Derivative of $P$. pentosaceus FBB63; $\mathrm{Rif}^{\mathrm{R}}$ & Negative $\left(\mathrm{Bac}^{-}\right)$ & $\mathrm{S}$ & I & This work \\
\hline
\end{tabular}

* Kindly provided by Lars Axelsson from MATFORSK, Norwegian Food Research Institute, Osloveien, Norway.

$614 \dagger$ Erm $^{\mathrm{R}}$ : resistant to erythromycin; Rif ${ }^{R}$ : resistant to rifampicin;

$615 \ddagger$ Resistant or Sensitive to bacteriocins produced by L. plantarum NC8

$616 \S$ Ability to induce bacteriocin production in co-culture with L. plantarum NC8 
a

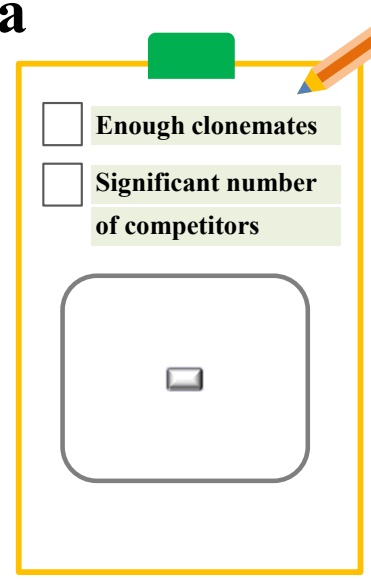

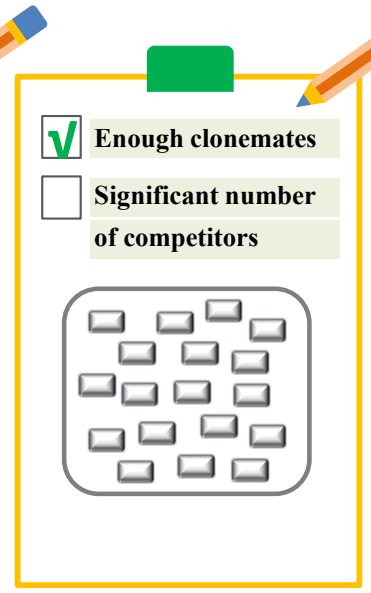
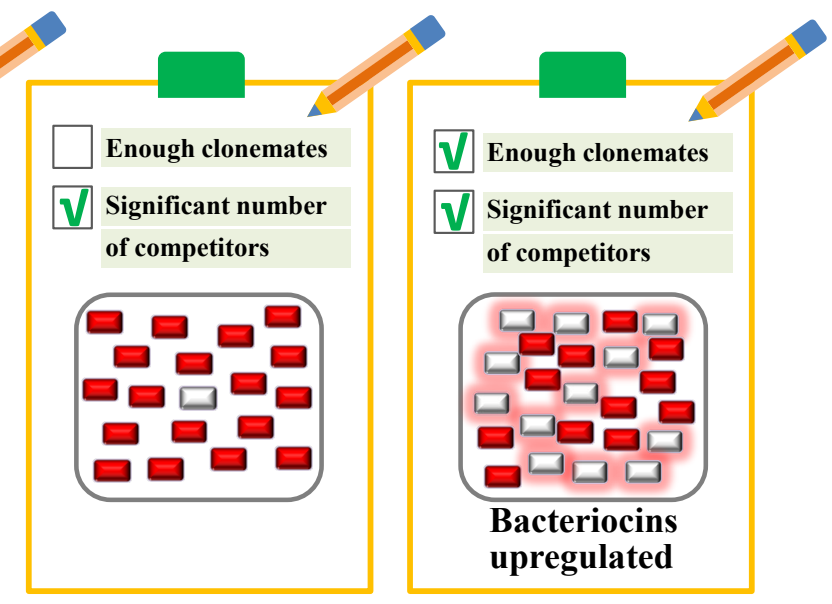

626

636

b

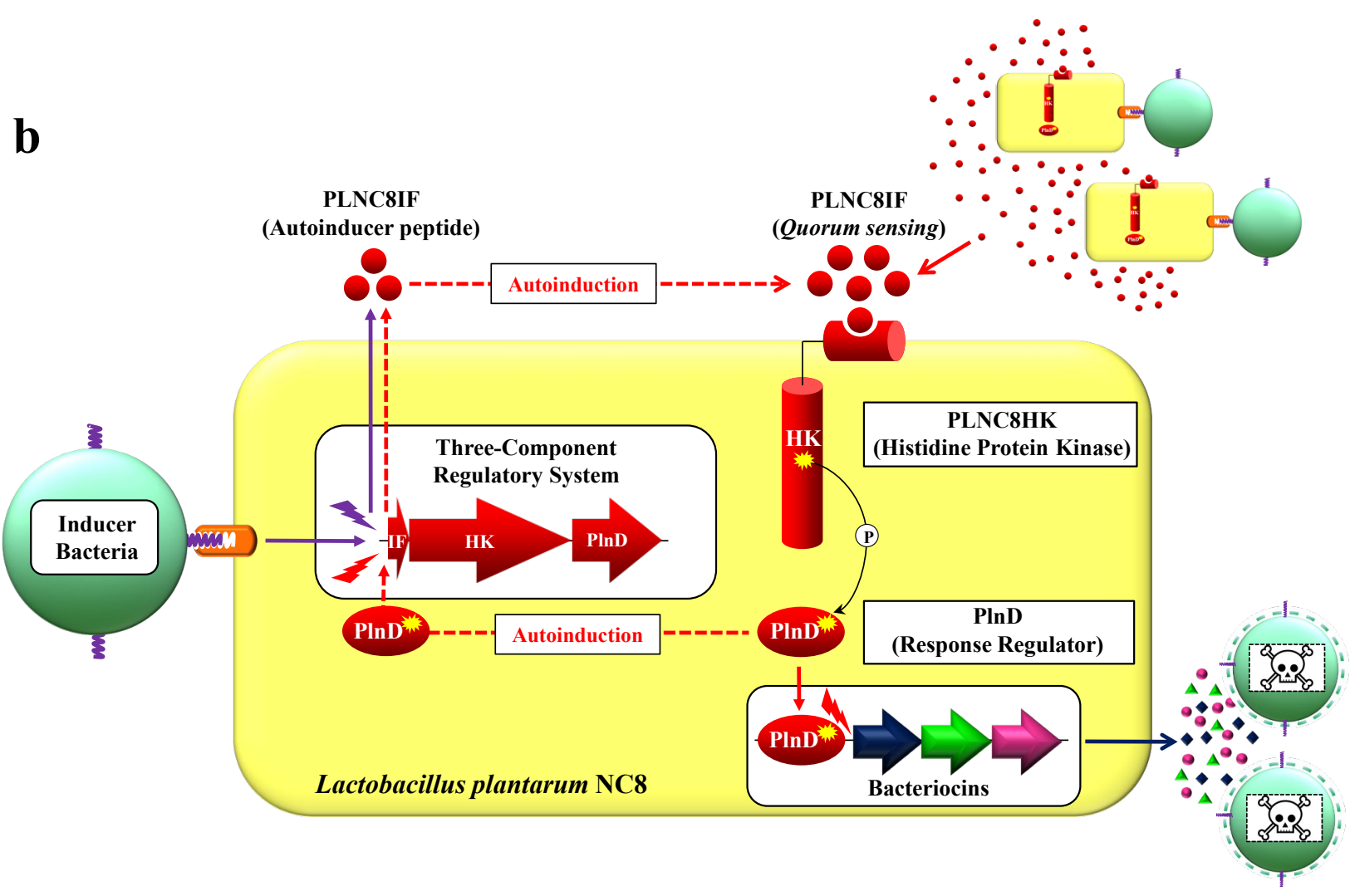


645 FIGURE 2

646

647 a

b
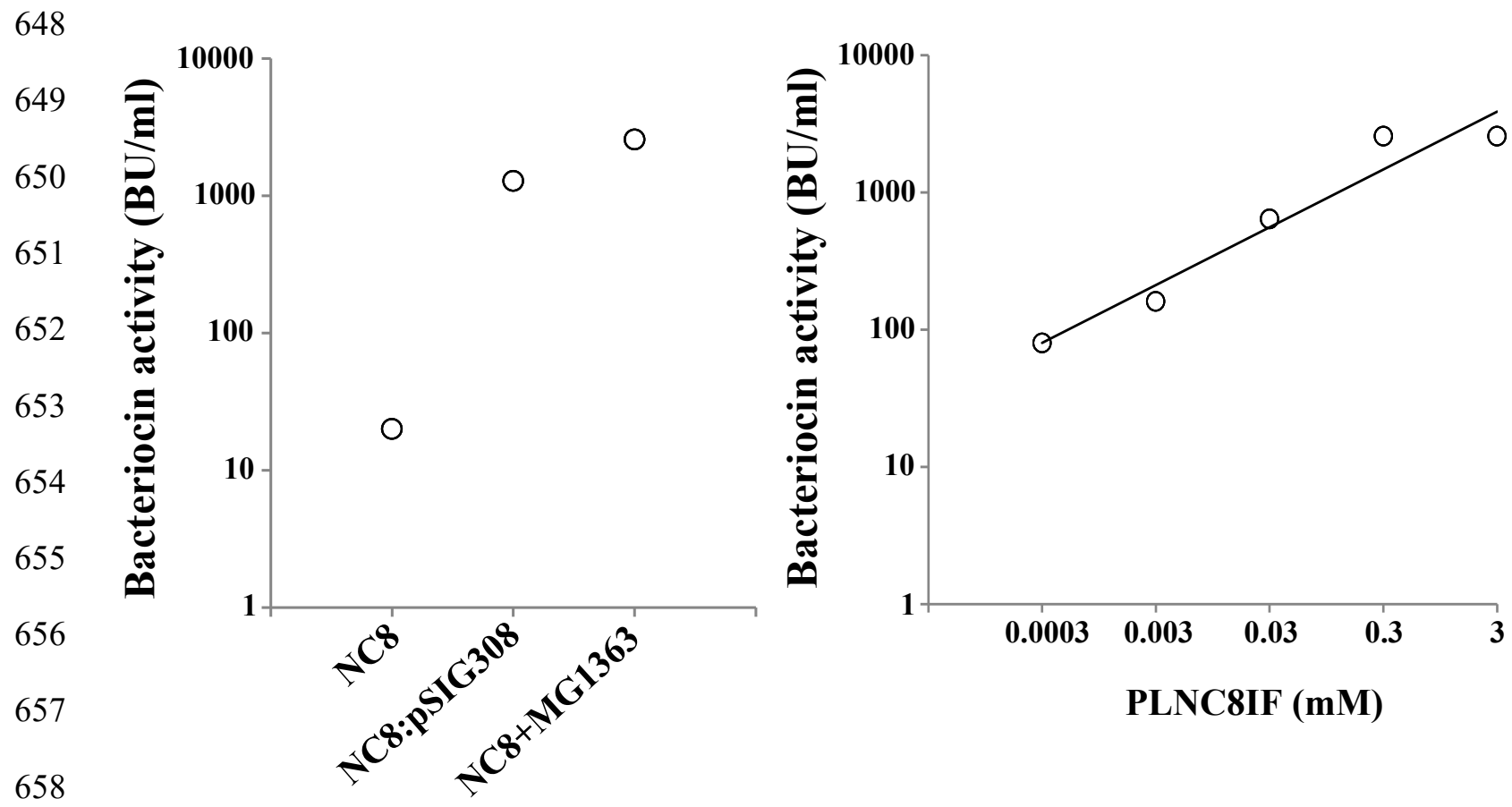

659

660

661

662

663

664

665

666

667

668

669

670

671

672 
674

675

a

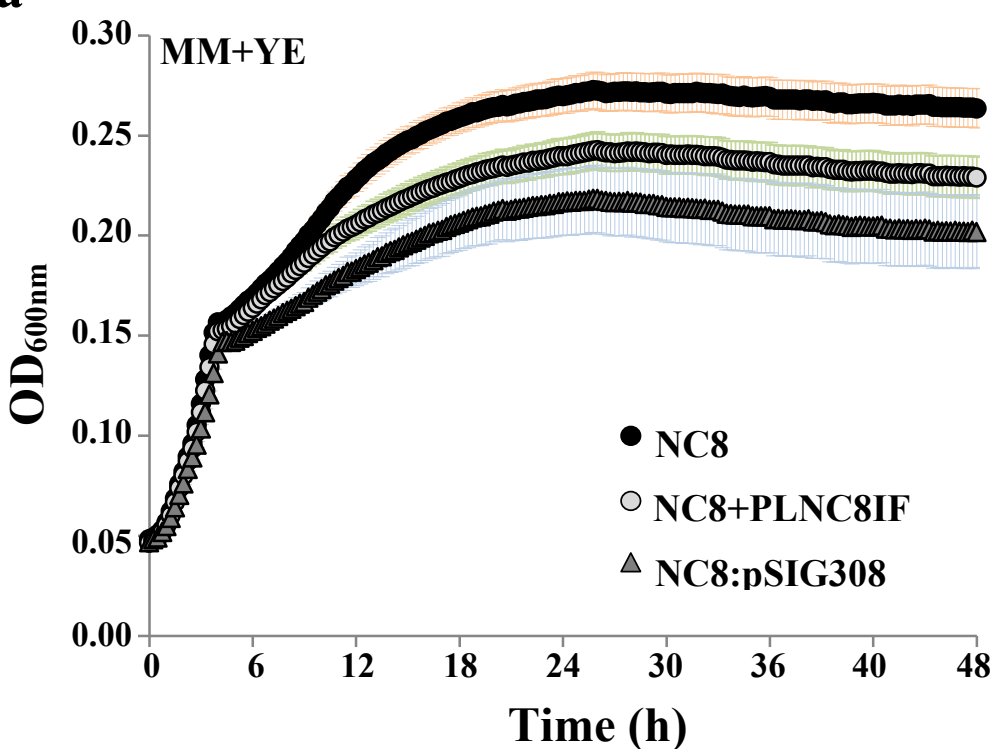

d

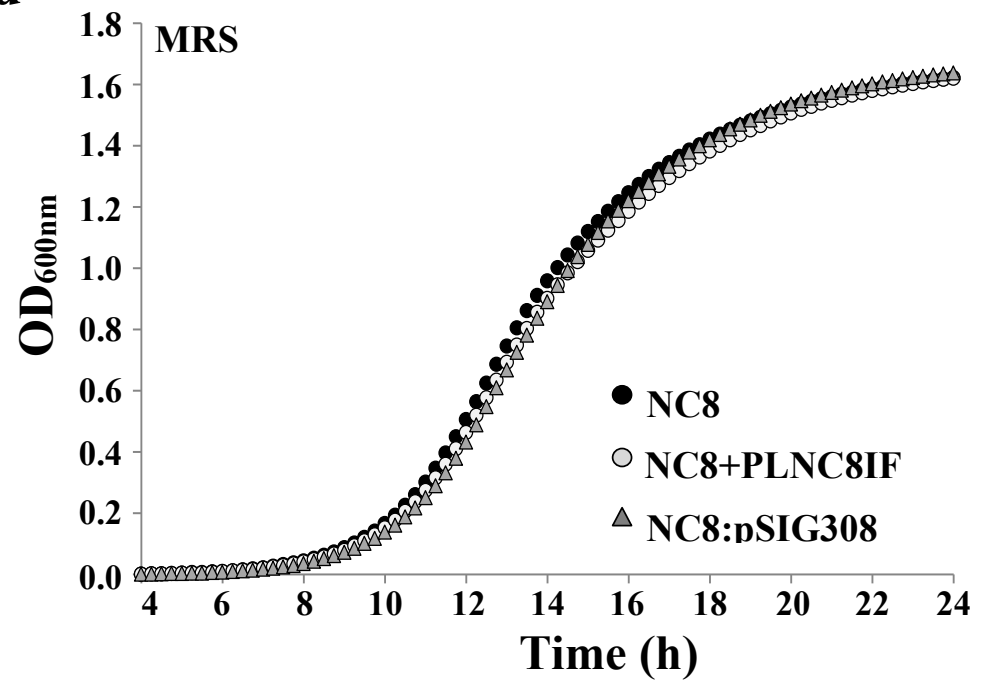

b

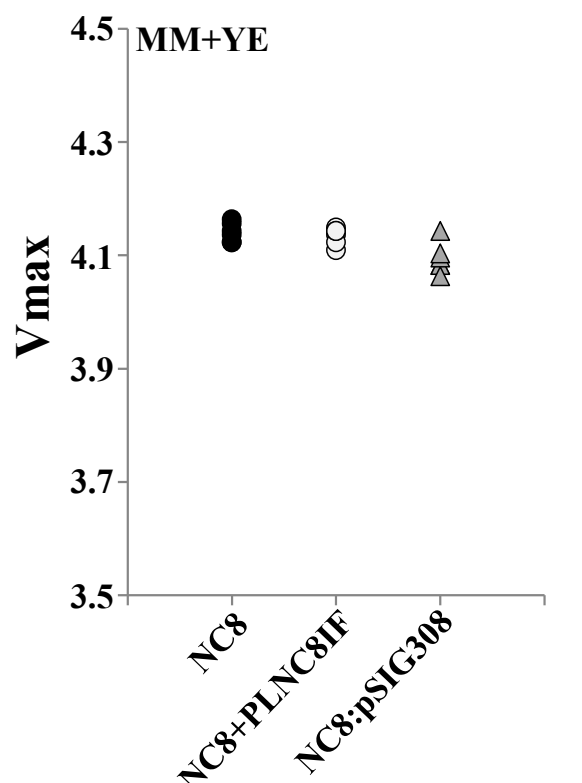

e

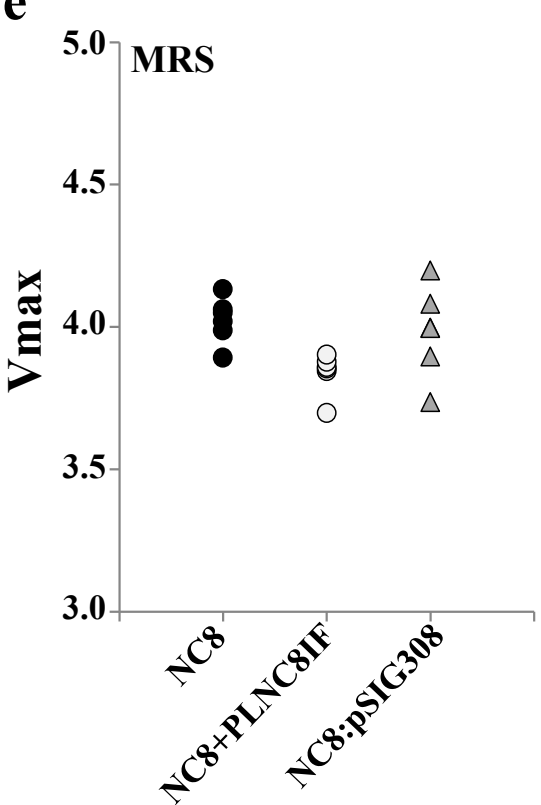

c

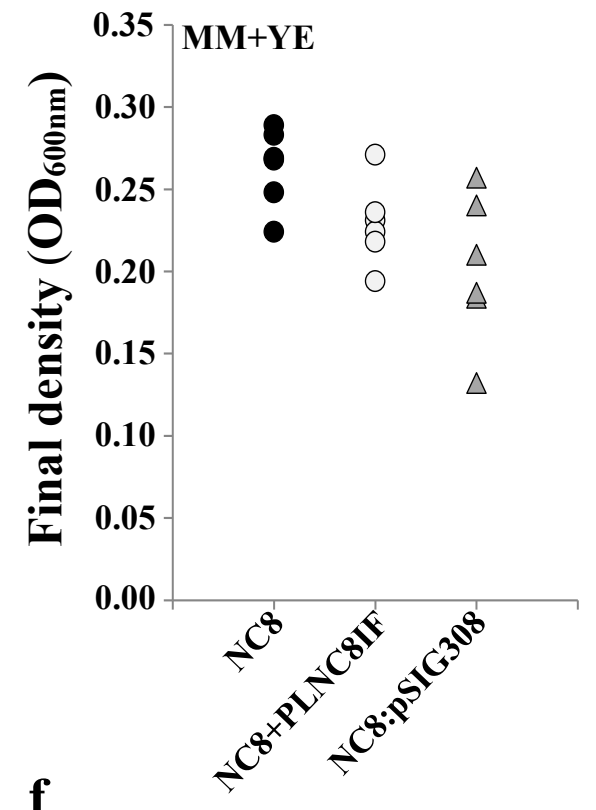

f

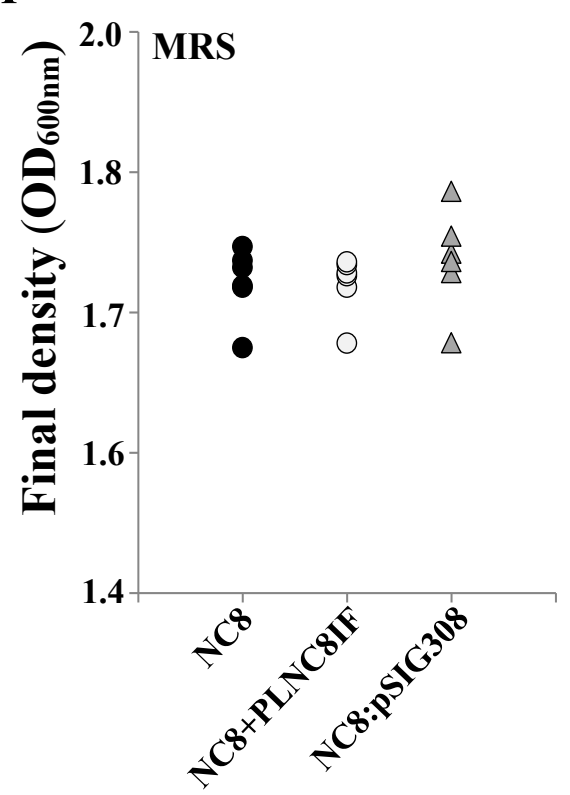


677

678

$\mathbf{a}$

b

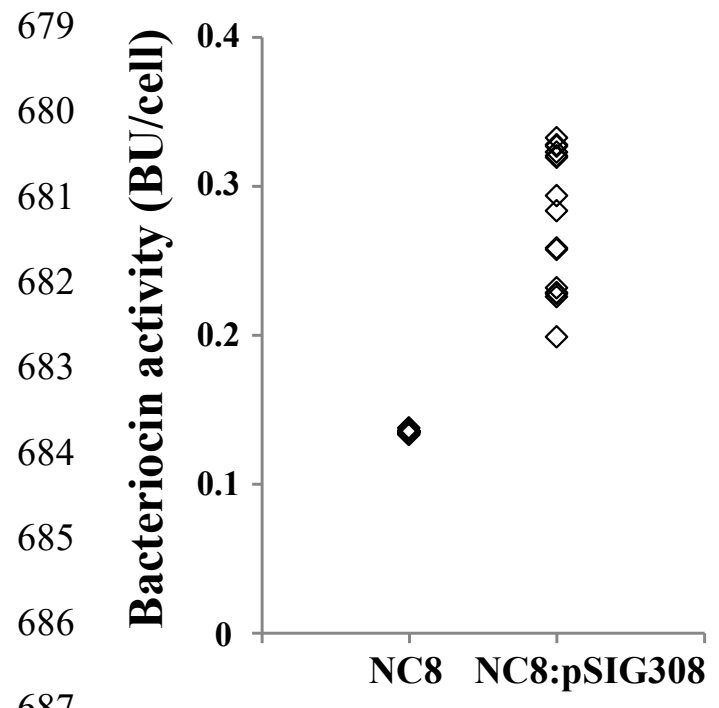

687

c

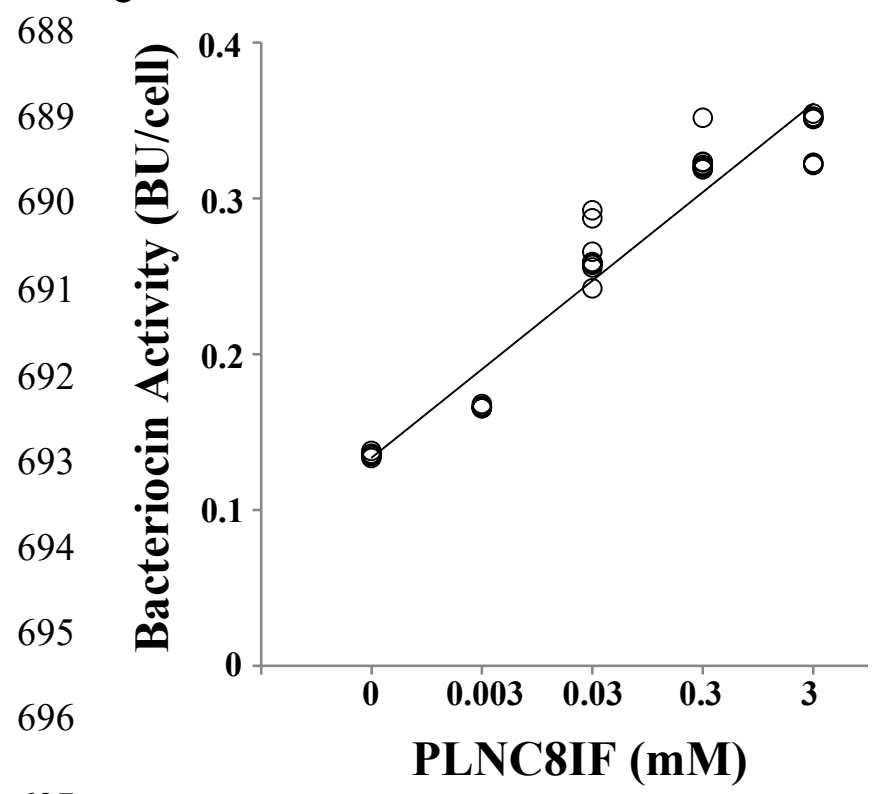

d
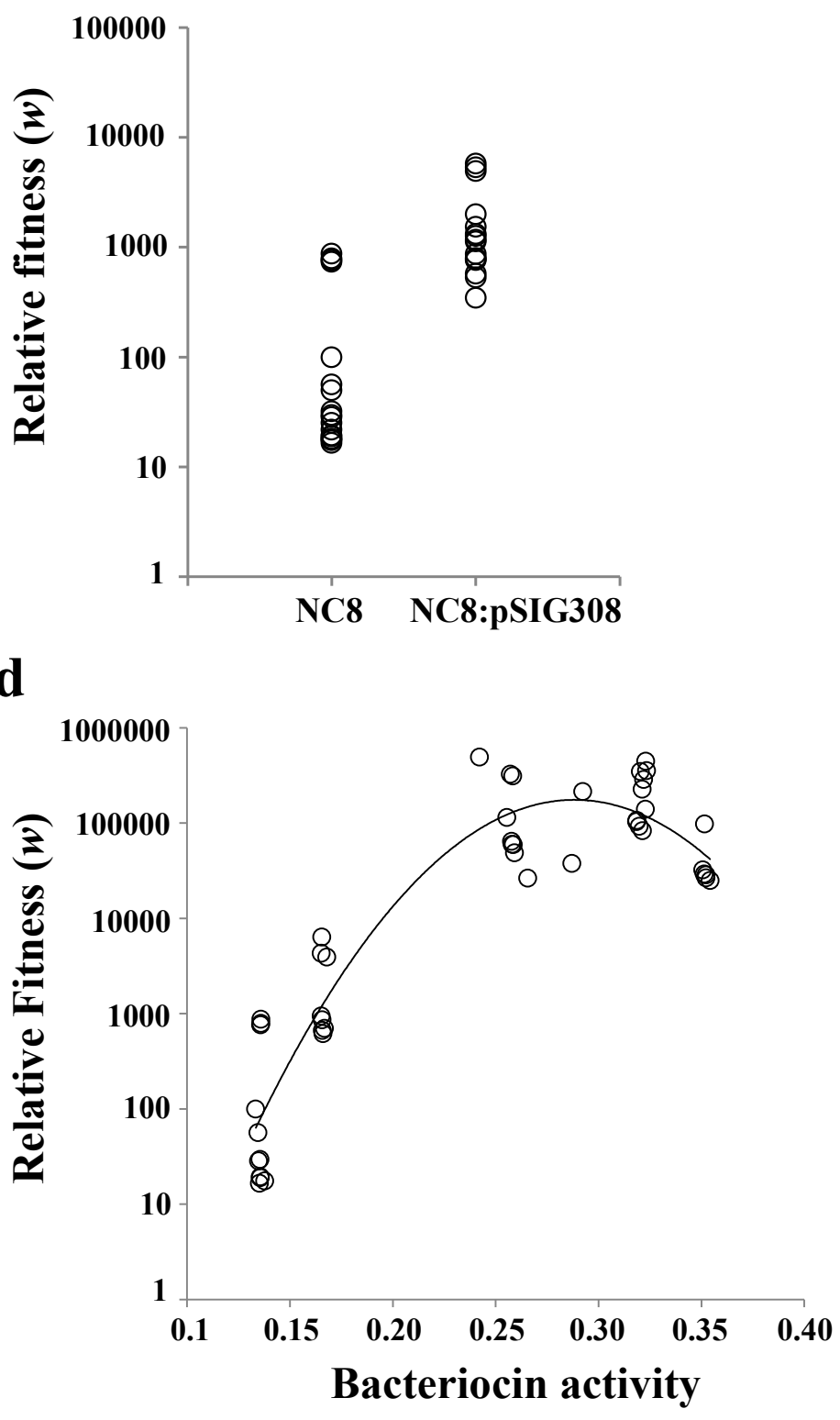
FIGURE 5

705

706

707

708

709

710

711

712

713

714

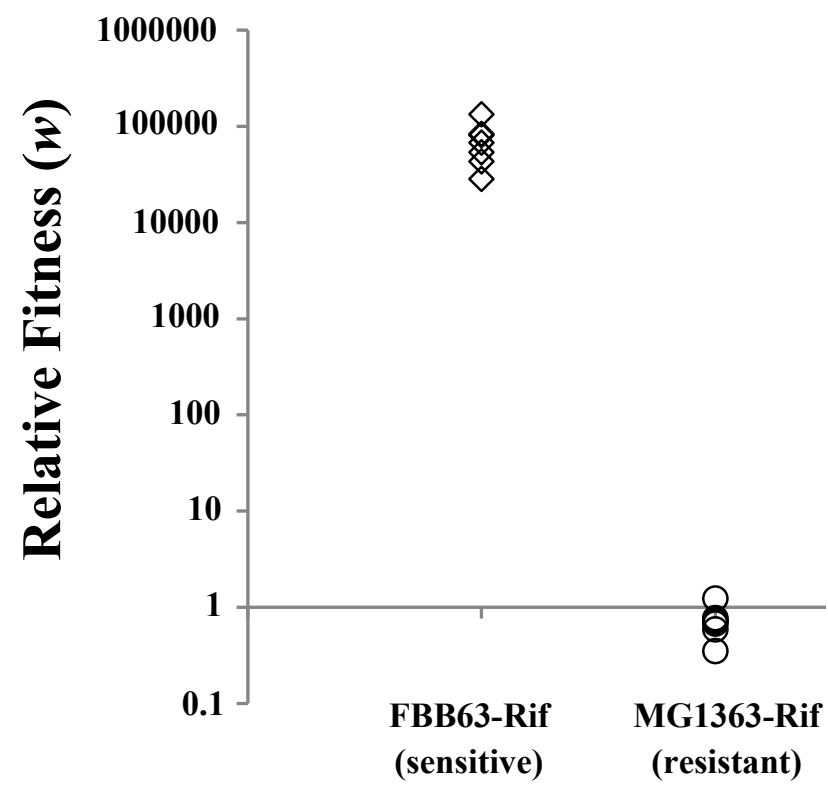

715

Inducer strains

716

717

718

719

720

721

722

723

724

725

726

727

728

729

730

731 
735

${ }_{736}$ a

b
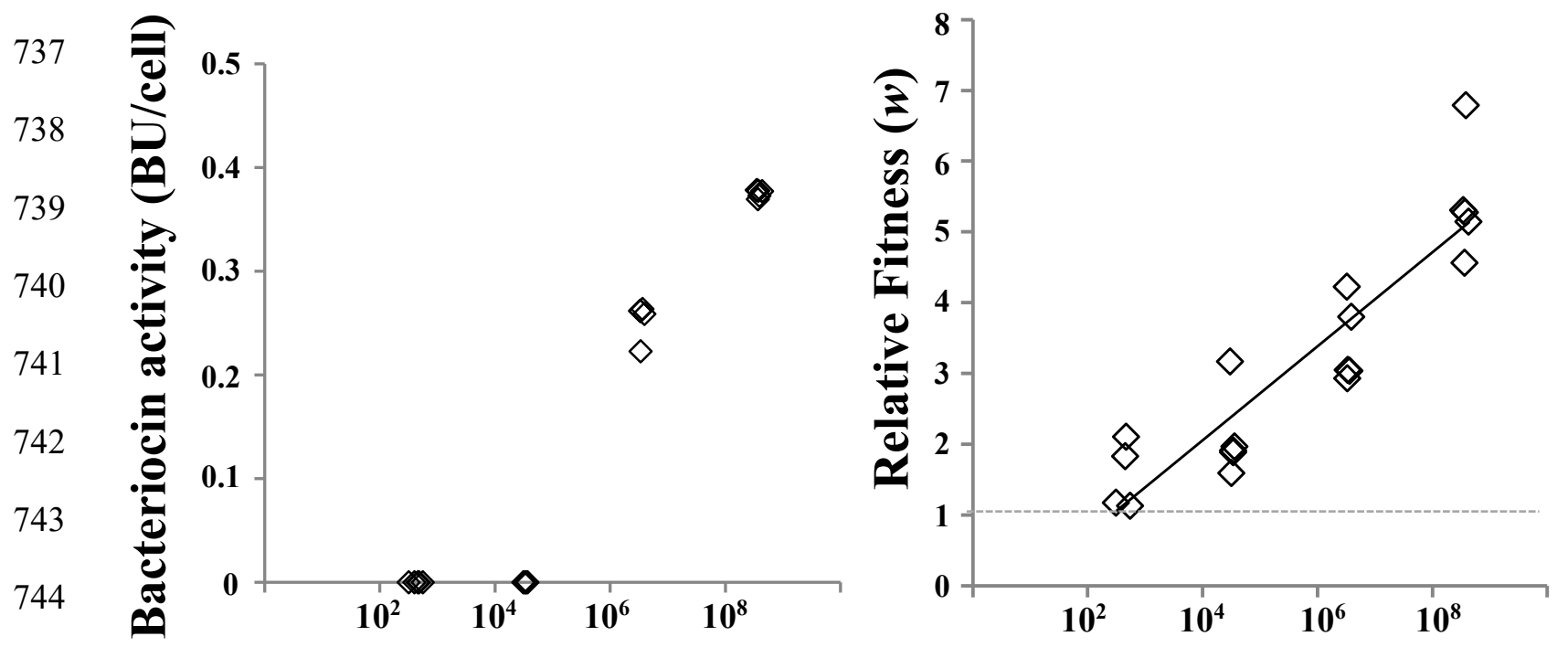

745

746

Cell Density (CFU/ml)

747

748

749

750

751

752

753

754

755

756

757

758

759 